\title{
Film kao ljekovita metafora u logoterapijskoj praksi
}

Irena Sever Globan* irena.sever@unicath.hr

Josip Bošnjaković** jobosnjakovic@gmail.com
UDK: 791.43:159.964.3

Izvorni znanstveni rad / Original scientific paper Primljeno: 30. siječnja 2016. Prihvaćeno: 11. travnja 2016.

Kako bi pomogao sebi ili drugome i poboljšao kvalitetu života, čovjek se koristi raznim tehnikama i sredstvima. U ovom članku polazi se od pretpostavke da su priče i vizualne metafore ljekovita sredstva za dušu ukoliko su iskrene, poticajne, utješne, nadahnjujuće, te na taj način mogu pomoći čovjeku u prevladavanju raznih psihičkih i egzistencijalnih tegoba. Posebni se naglasak stavlja na ljekovitost filmskih priča i filmoterapiju koja se sve češće koristi kao pomoćna tehnika u raznim psihoterapijskim pravcima, a nastavak je prakse biblioterapije koja se koristi i unutar logoterapije. Ta grana psihoterapije, koju je utemeljio Viktor Frankl, pokušava dati odgovor na pitanje egzistencijalne praznine koja sve češće tišti suvremenog čovjeka, a koja nastaje zbog nemogućnosti otkrivanja smisla. U članku se pokušava odgovoriti na pitanje kako filmske priče, koje se i same često vrte oko egzistencijalnih pitanja smisla (tko sam, odakle dolazim i kamo idem), mogu biti ljekovite ljudima koji se bore s pitanjem osmišljavanja vlastitog života te problemima patnje, slobode i odgovornosti, te koje filmove preporučiti klijentima u logoterapijskoj praksi (ali i ostalim psihoterapijskim pravcima).

Ključne riječi: film, psihoterapija, logoterapija, ljekovite priče, vizualne metafore.

\footnotetext{
* Doc. dr. sc. Irena Sever Globan, Odjel za komunikologiju, Hrvatsko katoličko sveučilište, Ilica 242, HR-10000 Zagreb.

*Dr. sc. Josip Bošnjaković, Odjel za psihologiju, Hrvatsko katoličko sveučilište, Ilica 242, HR10000, Zagreb; Katolički bogoslovni fakultet u Đakovu, Sveučilište Josipa Jurja Strossmayera, Petra Preradovića 17, HR-31400 Đakovo.
} 


\section{Uvod}

Život prosječnog čovjeka danas je nezamisliv bez upotrebe masovnih medija. Oni su ušli u sve sfere ljudskog života: koristimo ih u poslu, da bismo se zabavili u slobodno vrijeme, za religiozne prakse i duhovnost, traženje partnera, održavanje prijateljskih veza i još mnogo toga. Nerijetko upravo u medijskim sadržajima pronalazimo bijeg od svakodnevice; prepuštamo se fiktivnim pričama koje nas nose u neke druge, možda bolje svjetove. I dok virtualno ulazimo $u$ živote drugih, zaboravljamo na sebe i vlastite probleme. Uz medijske priče i likove koje prikazuju, uz njihove životne probleme, zavrzlame, radosti i tjeskobe, osjećamo da nismo sami. Kao moguća posljedica izloženosti medijskim naracijama javlja se i fenomen katarze ili pročišćenja, o čemu je govorio još Aristotel u svom promišljanju o utjecaju grčkih tragedija na publiku koja, proživljavajući emocije likova s pozornice, zajedno s njima doživljava i završno smirenje. ${ }^{1}$

Priče su odgovor na duhovne i psihičke potrebe čovjeka. Prepuštajući im se, mi u stvari tragamo za estetskim užitkom, fiktivno nastanjujemo jedan drugačiji svijet, ali i definiramo osobni i društveni identitet pitajući se zajedno s likovima: »Tko sam, odakle dolazim i kamo idem? ${ }^{2}$ Razlog je to zbog kojeg su fiktivne naracije konstantno prisutne u vremenu i prostoru. ${ }^{3}$ Talijanska sociologinja Milly Buonanno, koja se bavi proučavanjem društvenih funkcija televizijskih fiktivnih naracija, polazi od teze da su one današnjem čovjeku predragocjen materijal koji mu omogućuje da bolje shvati svijet u kojem živi. Tako imaginarno postaje stvarno ne samo zato što za vrijeme gledanja filma mi to vjerujemo, već i zato što mijenja našu percepciju pojedinih segmenata života kao i način na koji se prema stvarnosti odnosimo. ${ }^{4}$ Priče, bilo u književnosti bilo u filmu, govore nama i govore o nama, o temeljnim životnim iskustvima, o svemu onome što je predmet naših najintenzivnijih osjećaja i vrednota: ljubavi i mržnji, bolesti i zdravlju, prijevari i vjernosti, prijateljstvu i rivalstvu, razočaranjima i nadanjima. Likovi i situacije koje nam donose priče potencijalni su virtualni model s kojim se poistovjećujemo i kojeg u stvarnom životu možemo imitirati. ${ }^{5}$

Televizijski i filmski kritičar Robert McKee promišlja o tome kako se čovjek svakodnevno nalazi pred nizom izazova i izbora, a odabire one mogućnosti za koje vjeruje da će ga usrećiti. Da ne bi pogriješio u tom izboru, pojedinac prvotni izvor informacija traži u direktnom iskustvu, učeći na »vlastitoj koži«.

\footnotetext{
${ }^{1}$ Usp. Ivan DODLEK, Aristotelovo određenje tragičnoga, Metodički ogledi, 18 (2011) 2, 31-39.

2 Paolo BRAGA, La media serialità americana, u Gianfranco BETTETINI, Paolo BRAGA, Armando FUMAGALLI (ur.), Le logiche della televisione, Milano, Angeli, 2004, 226-227.

${ }^{3}$ Zanimljivo je proučiti etimološki korijen riječi naracija. Naime, ta riječ korijene vuče iz sanskrtskog jezika, dolazi od riječi »gna«, što znači znanje (riječ koja se u latinskom jeziku pretvorila $u$ »narro«) $i$ »gnarus« ili »spoznati, imati uvid u nešto«. Prema tome, glavne dimenzije naracije bile bi produbiti znanje i komunicirati ga u obliku priče.

${ }^{4}$ Usp. Milly BUONANNO, Realta multiple, Napoli, Liguori, 2004, 18-22.

${ }^{5}$ Usp. Milly BUONANNO, Leggere la fiction, Napoli, Ligouri, 1996, 24.
} 
Zatim uči i na iskustvima svojih bližnjih. Međutim, u davanju svakodnevnih smjernica važnu ulogu imaju i priče: budući da su one zaključen i organiziran oblik ljudskog iskustva (slikovito prikazuju uzročno-posljedične veze nekog djelovanja), čovjek u te priče projicira svoja pitanja, nesigurnosti, strepnje i u tom procesu pojednostavljivanja nada se da će dobiti jasnije ideje kojim smjerom krenuti kako bi bio sretan, te na kojim vrijednostima graditi vlastite izbore. ${ }^{6}$ Upravo iz tih razloga priče imaju važnu ulogu u životu čovjeka. One su naše bajke i mitovi, naše moralne pripovijesti, »vatra« uz koju »grijemo« naš ponekad hladan život i bez kojih možda ne bismo preživjeli kao ljudska vrsta. ${ }^{7}$ One su, jednom riječju, terapijske metafore koje su veoma važne za život i psiho-duhovni razvoj svakog pojedinca.

Čovjek danas do priča može doći putem raznih medija: knjige, televizijske serije, filma, radija, interneta. Težište našeg interesa u ovom je članku stavljen ipak na film kao medij koji pripovijeda koristeći audiovizualni jezik, a koji se, uz knjigu, danas najčešće koristi kao pomoćno sredstvo u psihoterapijskoj praksi. Nažalost, u široj je javnosti film kao takav još uvijek često percipiran kao medij čiji je primarni cilj zabava, dok se zaboravlja na one daleko važnije »nuspojave« te »sedme umjetnosti«: educirati, ohrabriti, potaknuti, dati uvid, osvijestiti, donijeti nadu, mijenjati (stavove, osjećaje, ponašanja). Film je medij koji kroz priču koju pripovijeda, istina i zabavlja, ali i poučava komunicirajući s gledateljem putem slika, simbola i metafora. Cora Moore će tako iz humanističko-egzistencijalne perspektive reći da su upravo te vizualne metafore "proces kroz koji se osoba može kretati prema duhovnoj razini, otkrivajući smisao, i iskušavajući život kao smislen i vrijedan življenja ${ }^{8}{ }^{8}$

Upravo će to biti polazišna točka teze koju želimo razraditi u ovom članku, a ona tvrdi da je film kao medij legitimna i korisna tehnika rada s klijentima u okviru psihoterapije, s posebnim naglaskom na egzistencijalno-humanistički pravac, logoterapiju. Logoterapija je psihoterapijski pravac koji se sve više primjenjuje i u Hrvatskoj te je od velikog značenja za suvremeno doba u kojem se bilježi porast psihičkih i duhovnih oboljenja poput noogenih depresija, egzistencijalnih kriza i gubitka smisla. Naime, bit logoterapije temelji se na uvjerenju da se u korijenu svake psihičke i psihosomatske bolesti nalazi nedostatak životnog smisla, tj. nemogućnost pronalaska smislenog životnog zadatka. Iz tog se razloga s klijentom, u okviru logoterapije, radi upravo na pronalaženju smisla njegova cjelokupnog života kao i životnih situacija u kojima se trenutno nalazi ili se nalazio, a koje mu stvaraju problem. Vjerujemo da se u sklopu te, danas sve raširenije psihoterapije koja čovjeka promatra kao cjelinu tijela, duše i duha, može koristiti i film kao jedna od pomoćnih tehnika u pronalaženju

\footnotetext{
${ }^{6}$ Usp. Robert McKEE, Story, Rim, International Forum, 2001.

7 Usp. Buonanno, Realta multiple..., 9.

${ }^{8}$ Cora MOORE, The use of visible metaphor in logotherapy, The International Forum for Logotherapy, 21 (1998) 2, 85-90.
} 
smisla. Filmoterapija bi tako bila kreativna terapijska tehnika u kojoj terapeut koristi film kao metaforu radi postizanja unutarnjeg uvida, sazrijevanja, promjene, izlječenja.

Pitanja na koja ćemo dati odgovor u ovome članku su sljedeća: u kakvom odnosu stoje film i psihoterapija/logoterapija? Je li korištenje filma u logoterapijske svrhe opravdano i ako da, u čemu bi se upotreba te tehnike točno sastojala? Koji filmovi su preporučljivi za rad s klijentima u logoterapiji? No, prije nego što krenemo »in medias res«, pogledajmo ukratko koja su osnovna polazišta Franklove logoterapije.

\section{Logoterapija kao liječenje smislom}

Grana psihoterapije koja nosi naziv »logoterapija«, a čiji je utemeljitelj bečki psihijatar Viktor E. Frankl (1905-1997), u svojoj je biti usmjerena prema tra-

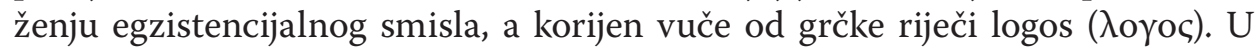
logoterapiji riječ logos ima dva značenja: $s$ jedne strane smisao, a s druge strane duhovnu dimenziju koja je svojevrsna kontrapozicija psiho-fizičkoj zadanosti. Logoterapija je definirana i kao treća bečka škola, koja slijedi nakon psihoanalize Sigmunda Freuda i individualne psihologije Adolfa Adlera. Ona se razlikuje od humanističkih psiholoških pristupa, iako je dio njih, u tome što tvrdi da cilj čovjeka nije samoaktualizacija, nego samotranscendencija. Nadilazeći samoga sebe čovjek se ostvaruje te se zadovoljstvo vraća njemu u krilo kao posljedica pronađenog smisla (efekt bumeranga). ${ }^{9}$ Također, po prvi se puta u području psihijatrije i psihoterapije na čovjeka počinje gledati kroz tri dimenzije: tijelo, psihu i duh. Dakle, logoterapijska antropologija izbjegava pogled na čovjeka kao na psihofizičku zadanost koja se u svakom trenutku može razboljeti, već stavlja naglasak upravo na čovjekov duh koji uvijek ostaje zdrav, samo ponekad sakriven zbog bolesti psihofizičkog aparata.

Prema Franklu, čovjek je pozvan otkriti i tražiti smisao i značenje života budući da je samo tako sposoban odgovoriti na egzistencijalnu prazninu u kojoj se može naći zbog nedostatka smisla. ${ }^{10}$ Nasuprot mogućnosti osmišljavanja života, čovjek je odgovoran i osjeća potrebu postaviti si ne općenito pitanje poput: »Koji smisao ima život?«, već specifično pitanje: »Koji smisao ima moj život?« Na ovo pitanje pojedinac je pozvan sam sebi dati odgovor, što postaje izričaj onoga što je u čovjeku najljudskije. ${ }^{11}$

Frankl je u teoriji logoterapije snažno naglašavao činjenicu da je čovjek duhovno biće. Po toj duhovnoj dimenziji čovjek može biti pri, kod drugog bića

\footnotetext{
${ }_{9}$ Viktor FRANKL, Logoterapia. Medicina dell'anima, Brescia, Queriniana, 2001, 81.

${ }^{10}$ Usp. isto, 82.

${ }^{11}$ Usp. Viktor FRANKL, Logoterapia e analisi esistenziale, Brescia, Morcelliana, 2005.
} 
(»bei« anderem Seienden $z u » s e i n «){ }^{12}$ Kad osoba gleda film ili pak čita neku knjigu, ona upravo po svojoj duhovnoj dimenziji biva prisutna kod ili pri drugoj, iako fiktivnoj osobi. I tek onda kada je s drugom osobom, kod druge osobe, ona u punini ostvaruje svoju egzistenciju. Dapače, Frankl naglašava kako se osobe ostvaruju tek onda kada se u potpunosti prepuštaju jedna drugoj, a što će on nazvati ljubavlju. Ljubav prema drugoj osobi, ali i prema samome sebi, doprinosi tome da čovjek ne vidi u drugome i u sebi tek neku gotovu realnost, »nego također i jednostavnu mogućnost, nešto što još ne postoji ali je u nastajanju, što može i treba postati« ${ }^{13}$ I ova dimenzija se često pojavljuje u pričama. Zar se čovjeku ne događa, dok čita knjigu ili gleda film u kojima su protagonisti osobe vrijedne nasljedovanja, da si i sam postavi pitanje: »Zašto ja ne bih mogao biti sličan ovoj osobi? « Jer na koncu, svaka je osoba otvorena, bezuvjetna mogućnost koja se može realizirati na različite načine.

Polazeći od pretpostavke da je čovjek duhovno biće, Frankl naglašava da je čovjek i biće slobode. Čovjek je sposoban ponašati se i na drugačiji način pa i onda kada ga okolnosti velikim dijelom uvjetuju. ${ }^{14}$ Ovu sposobnost Frankl naziva noopsihičkim antagonizmom (der fakultative noo-psyschische Antagonismus), što bi značilo sposobnost biti slobodna osoba nasuprot uvjetovanostima i okolnostima koje čovjeka pritišću na psihofizičkoj razini, a samim time ipak stvaraju mogućnost da se očituje njegova duhovna autonomija. ${ }^{15}$ Čovjek nije samo jedan element u prirodi ili pak biološki organizam, nego je on otvorena mogućnost, živuće i odgovorno biće koje je oduvijek bilo sposobno reagirati u odnosu s okolinom, mijenjati je, pa i onda kada je u mnogočemu uvjetovan. ${ }^{16}$

Uzimajući pak u obzir govor o odgovornosti čovjeka, Frankl tvrdi da je čovjek odgovoran pred životom koji mu postavlja pitanja. Odgovori se konkretiziraju i realiziraju ad personam i ad situationem. Živjeti, u konačnici, ne znači drugo nego biti odgovoran u odgovaranju na vitalne probleme, $u$ ispunjavanju zadataka koje nam život postavlja, suočavati se s potrebama i zahtjevima nekog trenutka. ${ }^{17}$ Koliko su upravo teme ljudske slobode, odgovornosti i čovjekovog duha sveopće teme te se upravo one često obrađuju u književnim i filmskim umjetničkim djelima.

Čovjeka se kroz povijest definiralo u različitim terminima. Aristotel je, na primjer, čovjeka nazvao homo politicus, društvo će danas definirati čovjeka kao homo faber, homo videns ili homo ludens. Frankl je pak čovjeka nazvao homo

\footnotetext{
${ }^{12}$ Usp. Frankl, Logoterapia..., 74-87.

${ }^{13}$ Usp. isto.

${ }^{14}$ Usp. isto.

${ }^{15}$ Eugenio FIZZOTTI, Che senso ha vivere se si è così condizionati? Attorno al paradigma frankliana della libertà, Ricerca di senso, 3 (2005) 2, 177-199.

${ }^{16}$ Fiorella CAPPELLINNI VERGARA, Paola IBBA, Marilena TACCONI, Unicità e complessità dell'essere umano. Proposta di un modello integrato di psicoterapia, Assisi, Citadella, 1999, 37.

${ }^{17}$ Usp. Viktor FRANKL, Zašto se niste ubili, Zagreb, Svijetla točka, 1978.
} 
patiens: čovjek patnik..$^{18}$ Oblike ljudskog iskustva koji se očituju kroz patnju, smrt i krivnju, ovaj je bečki psihijatar nazvao tragičnom trijadom. Patnja je bez sumnje sastavni dio ljudskog života, te je u tom smislu ona vrlo često i tema koja se obrađuje kroz filmske priče. To može biti patnja pojedinca, zajednice, društva ili svijeta. Također to može biti duhovna, duševna, tjelesna, fizička, psihička, ekonomska ili neka druga patnja. Upravo filmovi s ovakvim temama omogućuju čovjeku da, poistovjećujući se s jednim likom ili više njih, pronalazi rješenje za svoju trenutnu situaciju.

Čovjek, i kada pati, i kada je uvjetovan raznim okolnostima, on je sposoban ostvarivati vrijednosti stava. Tako, na primjer, u filmu Nedodirljivi redatelja Oliviera Nakachea i Érica Toledana, bogati aristokrat i kvadriplegičar Philippe uz pomoć siromašnog mladića Drissa ostvaruje na izvrstan način upravo vrijednosti stava dopuštajući si biti u potpunosti ovisan o drugome i osmišljavati svoj život usprkos patnji i bolesti. Stoga, ako lik iz nekog filma, koji prolazi kroz životne krize i probleme (poput gubitka voljene osobe, rastave, smrti djeteta, depresija, pokušaja suicida, problematičnih partnerskih odnosa, svađe s roditeljima, fobija i sl.), na kraju pronalazi u tome smisao te postaje jači i bolji nego što je bio na početku priče, taj lik može postati uzorom osobi koja se nalazi u sličnoj situaciji.

\section{Značenje priča u psihoterapijskoj i logoterapijskoj praksi}

Tvrdnja da su priče ljekovite i da mogu poslužiti u psihoterapijske svrhe nije novijeg datuma. Tehnika biblioterapije, koja doslovno znači »liječenje knjigom « ${ }^{19}$ ili »korištenje književnosti i poezije u liječenju ljudi s emocionalnim problemima ili mentalnom bolešću « ${ }^{20}$ poznata je od davnina. Tako je na vratima knjižnice $u$ antičkom gradu Tebi pisalo: »Ljekovito mjesto za dušu«. Također, u SAD-u, u 19. stoljeću neke su se knjige, poput McGuffey Readers i The New England Primer, koristile kako bi razvijale karakter i prosocijalne vrijednosti u djece. ${ }^{21}$ Upravo se u drugoj polovici 19. stoljeća u SAD-u počinje razvijati suvremena klinička biblioterapija kao pomoćna disciplina u psihijatrijskom liječenju nakon što se uvidjelo da razgovor o tekstu ili samostalno pisanje proze i poezije utječu na brže izlječenje pacijenata sa psihičkim oboljenjima. U kliničkoj praksi pisani se tekstovi koriste da bi pružili neku informaciju, potaknuli raspravu i dali nov unutarnji uvid o konkretnom problemu, komunicirali nove stavove i

\footnotetext{
${ }^{18}$ Usp. Viktor FRANKL, Homo patiens. Soffrire con dignità, Brescia, Morcelliana, 2001, 15.

${ }^{19}$ John T. PARDECK, Jean A. PARDECK, An ovierview of the bibliotherapeutic treatment approach: implications for clinical social work practice, Family Therapy, 11 (1984) 3, 241-252, 241.

${ }^{20}$ Usp. John T. PARDECK, Recommended self-help books for families experiencing divorce: a specialized form of bibliotherapy, Psychotherapy in Private Practice, 15 (1996) 1, 45-58, 51.

${ }^{21}$ Isto, 45.
} 
vrijednosti, osvijestili da i drugi imaju slične probleme, ponudili rješenja problema. ${ }^{22}$ No isto tako poznajemo i interaktivnu, tj. edukacijsku biblioterapiju koja je usmjerena na rad sa zdravim pojedincima, a gdje tekst postaje poticaj za rad na vlastitom samopouzdanju, razvoju kreativnosti i mašte, stvaranju međuljudskih odnosa, upoznavanju i oslobađanju emocija, poboljšanju pisanih i govornih kompetencija.

Iako se biblioterapija koristi u mnogim psihoterapijskim pravcima, kao i u ustanovama koje se bave osobnim razvojem zdravog pojedinca, ovdje nas posebno zanima koja je uloga priča u logoterapiji. Frankl je na temelju svoje dugogodišnje psihijatrijske prakse izjavio da je »prava knjiga u pravo vrijeme mnoge ljude sačuvala od samoubojstva « pa »u tom smislu knjiga pruža istinsku pomoć u životu - i u smrtnom času «. ${ }^{23}$ I sama Franklova knjiga Život uvijek ima smisla (Zašto se niste ubili?) mnogima je pružila nadu u teškim životnim trenucima. ${ }^{24}$ U svojoj knjizi Duhovna psihologija, logoterapeutkinja i Franklova učenica Elisabeth Lukas, uvodi nas u pojam »ljekovitih priča« $\mathrm{i} » l j e k o v i t o s t i$ čitanja« kao važnog dijela logoterapije. Ona tvrdi, ako logoterapeut svom klijentu ponudi pravu priču u pravi trenutak, ona može odigrati veću ulogu od bilo koje seanse:

»I tada se može dogoditi nešto fenomenalno: odjednom osjetimo ključanje izvora prepunih smisla. ${ }^{25}$

Kittler, u okviru logoterapijskog učenja, tvrdi da životne sudbine koje se nalaze u pripovijestima djeluju duboko na čitatelja dopirući do njegovih najdubljih slojeva. ${ }^{26}$ Muth pak ljekovitu ulogu priča vidi u njihovoj moći da u čitatelju izazovu

»smijanje i plakanje, suosjećajnost i fantaziranje, poistovjećivanje sa sudbinom drugih i povlačenje u vlastitu prošlost, pribiranje iz rastresenosti, svladavanje dubine, meditiranje ${ }^{27}$

dok Raab smatra da

»čitanje kojemu se egzistencijalno prepuštam pruža šansu da u sebi pokrenem proces dubinskog, egzistencijalnog dozrijevanja, da u meni proradi savjest koja napokon vodi vedrijem opuštanju koje u pogodnim okolnostima može uroditi spasenjem i oslobođenjem ${ }^{28}$.

\footnotetext{
${ }^{22}$ John T. PARDECK, Jean A. PARDECK, Bibliotherapy. A guide to using books in clinical practice, San Francisco, Mellen Research University Press, 1992.

${ }^{23}$ Elisabeth LUKAS, Duhovna psihologija, Đakovo, UPT, 2006, 75.

${ }^{24}$ Frankl, Zašto se niste ubili..., 9.

${ }^{25}$ Lukas, Duhovna psihologija..., 74.

${ }^{26}$ Usp. Udo KITTLER, Friedhelm MUNZEL, Was lese ich, wenn ich traurig bin, Freiburg, Herder, 1984.

${ }^{27}$ Peter RAAB (ur.), Heilkraft des Lesens, Freiburg, Böschemeyer, 1988, 33-34.

${ }^{28}$ Usp. isto.
} 
A kada je riječ o bajkama, Betz primjećuje da se iza njih »krije čvrsto pouzdanje da sve otežavajuće okolnosti mogu biti svladane «. ${ }^{29}$

Iako se ovi autori bave egzistencijalnom dimenzijom prvenstveno pisanih priča koje se klijentima mogu sugerirati da bi osvijestili smisao bolne situacije te pronašli smisleni izlazak iz krize, pojam »ljekovitih priča« može se primijeniti i na one filmske. Književnost i film dijele iste osnovne elemente pripovijedanja. Čitanje priče ili gledanje filma može osobi pomoći da dođe do novog uvida u vlastitu stvarnost, situaciju i probleme. Wolz tako vjeruje da se korištenje filmova za osobni rast i liječenje nadovezuje na tradiciju odnosa pričanja priča i samorefleksije. ${ }^{30}$ Oba spomenuta medija koriste pregršt metafora koje čovjeku pomažu da se distancira od proživljenih iskustava te postane protagonist u osobnim životnim pričama, sposoban da pronađe nova moguća rješenja i prekorači most između onoga što jest i onoga što bi moglo biti. Baš kao i bajke, mitovi, legende, pučke narodne pripovijesti, parabole ili prispodobe vjerskog karaktera (koje je, na primjer, Isus rado koristio u naviještanju Božjeg kraljevstva), tako i mnoga filmska ostvarenja sadrže pouke i obećanja, utjehu i nadu. Solomon upravo filmove naziva »ljekovitim pričama ${ }^{31}$ jer ono što likovi proživljavaju u filmovima često klijenti prolaze u stvarnom životu pa se može između dva života, virtualnog i stvarnog, napraviti poveznica i iz toga učiti, te posljedično mijenjati. Dakle, kroz naraciju koja pripovijeda o nekom drugom, čovjek može dobiti uvide u nove mogućnosti i nove obrasce djelovanja. ${ }^{32}$

Recimo još da je temeljna razlika između ove dvije forme pripovijedanja sam medij prenošenja: $u$ biblioterapiji je to fizički medij tiskane knjige, dok se $u$ slučaju filmske priče radi o elektroničkom audiovizualnom zapisu koji je pohranjen na tvrdom disku. Također, čitanjem upravljamo slobodnije jer sami odlučujemo u kojem ćemo trenutku stati, želimo li se vratiti na ono već pročitano, dok je kod gledanja filma to nešto teže. ${ }^{33}$ Tako bi film i filmoterapija bili logičan nastavak biblioterapije koja poznaje dugu praksu u psihoterapijskom (i logoterapijskom) liječenju.

\footnotetext{
${ }^{29}$ Usp. Lukas, Duhovna psihologija..., 77.

${ }^{30}$ Usp. Birgit WOLZ, E-motion picture magic. A movie lover's guide to healing and transformation, Centennial, Glenbridge Publishing, 2005.

${ }^{31}$ Gray SOLOMON, The motion picture prescription. Watch this movie and call me in the morning, Santa Rosa, Aslan Publishing, 1995, xiv.

${ }^{32}$ Usp. Abby CALISCH, From reel to real. Use of video as a therapeutic tool, Afterimage. The journal of media arts and cultural criticism, 29 (2001) 3, 22-24.

${ }^{33}$ Više o razlikama između knjiga i filma usp. Elizabeth LUKAS, Što nas u životu pokreće. Logoterapijski pristup, Zagreb, Svijetla točka, 120-123.
} 


\section{Metoda filmoterapije u psihoterapijskoj praksi}

Korištenje filma u psihoterapiji relativno je nova terapijska praksa, iako postoje podaci da se film kao priručno pomagalo koristio već u četrdesetim godinama 20. stoljeća. ${ }^{34} \mathrm{U}$ anglosaksonskom govornom području korištenje filma u psihoterapiji naziva se cinematherapy, što bi se na hrvatski prevelo $\mathrm{s}$ »filmoterapija«. Valja svejedno naglasiti da filmoterapija kao samostalan oblik terapijske prakse još službeno ne postoji niti su rađena neka značajnija eksperimentalna istraživanja o tome. Film kao pomoćno terapijsko sredstvo koristi se u individualnoj, grupnoj, obiteljskoj psihoterapiji, te u psihoterapiji s parovima, kao i s djecom i mladima. Također, koristi se u brojim psihoterapijskim pravcima: psihoanalizi, psihodinamici, kognitivno-bihevioralnom, humanističkom i logoterapijskom pravcu. ${ }^{35}$

Pojam »filmoterapija« u stručnoj se literaturi prvi put pojavljuje 1990. godine, a definira se kao »terapijska tehnika u kojoj terapeut izabire komercijalne filmove da ih klijent pogleda sam ili s nekim drugim « u terapijske svrhe. ${ }^{36}$ Calisch filmoterapiju opisuje kao terapijsku tehniku u kojoj terapeut nakon pažljivog odabira savjetuje klijentu određeni film, o čemu zatim raspravlja u okviru terapijske seanse.$^{37}$ Gledanje filma »često može klijentima dati novu perspektivu za promatranje 'likova' u vlastitom životu te im pružiti jasniji uvid u kompleksnost bliskih interpersonalnih odnosa «. ${ }^{38}$ No valja naglasiti da se na film kao pomoćnu tehniku u psihoterapiji ne smije gledati kao na neku čarobnu pilulu koju bi se propisalo na recept te koja bi instantno izliječila npr. opsesivno-kompulzivni poremećaj ili neku noogenu neurozu, već je film dio terapijskog procesa, tj. sredstvo koje pomaže ljudima da brže ostvare napredak u terapiji. ${ }^{39}$

Većina autora koji su u svojoj praksi koristili filmoterapiju definiraju film kao »terapijsku metaforu«. Christie i McGrath definiraju je kao posebnu vrstu priča ispričanih s namjerom da poduče ili savjetuju, a metaforički jezik koji koriste trebao bi klijentima srušiti obrambene mehanizme. Naime, metafore aktiviraju podsvjesne obrasce asocijacija te utječu na stvaranje novih odgovara

\footnotetext{
${ }^{34}$ Usp. Elias KATZ, A brief survey of the use of motion pictures for the treatment of neuropsychiatric patients, Psychiatric Quarterly Supplement, 20 (1946), 204-216.

${ }^{35}$ Usp. Danny WEDDING, Movies and Psychotherapy: Using Films to Facilitate Rapport and Enhance Personal Growth, APA Convention, Moscone Center, San Francisco, 25. kolovoza 2001; Danny WEDDING, Ryan NIEMEC, The clinical use of films in psychotherapy, JCLP/In Session. Psychotherapy in Practice, 59 (2003) 2, 207-215.

${ }^{36}$ Usp. Linda BERG-CROSS, Pamela JENNINGS, Rhoda BARUCH, Cinematherapy. Theory and application, Psychotherapy in Private Practice, 8 (1990) 1, 135-156.

${ }^{37}$ Usp. Calisch, From reel to real...

${ }^{38}$ Melissa A. HESTON, Terry KOTTMAN, Movies as Metaphors. A Counseling Intervention, Journal of Humanistic Education and Development, 36 (1997), 92-99, 92.

${ }^{39}$ Usp. Jan HESLEY, Reel therapy. Movie are the hot new prescription, Psychology Today, 33 (2000) 1, 54-57.
} 
i ponašanja u sadašnjoj svjesnosti. ${ }^{40}$ Stoga je cilj terapijskih metafora podučiti, a to se događa tek kada se klijent poveže i identificira s filmskom pričom i likovima te onda primijeni priču i njene moralne implikacije na vlastiti život, što pomaže u procesu samorazumijevanja i samoiscjeljenja. Heston i Kottman smatraju da osjećaj podijeljenog iskustva koje proizlazi iz metafore omogućuje umanjivanje klijentova osjećaja izolacije i egzistencijalne usamljenosti. ${ }^{41}$

Filmovi se dakle koriste da bi educirali klijente o njihovim problemima, pomogli im da otvorenije progovore o vlastitim kriznim situacijama o kojima im je inače teško govoriti, unaprijedili empatiju i olakšali razumijevanje tuđih gledišta, te pozitivniji i produktivniji odnos između klijenta i psihoterapeuta. ${ }^{42}$ Uz to, ostali pozitivni učinci gledanja filmova u psihoterapijskoj praksi koji se spominju u literaturi odnose se i na pružanje osjećaja nade i optimizma u odnosu na problem koji klijenta muči, kao i alternativnih oblika misli i djelovanja; zatim poticanje komunikacije između supružnika i članova obitelji, te stvaranje boljeg uvida u problem i vlastitu nutrinu, a što može dovesti do ozdravljujućeg emotivnog iskustva ${ }^{43}$ Film tako postaje plodno tlo za razgovor klijenta i terapeuta. Naime, nužno je da se o filmu koji je klijentu sugeriran kasnije razgovara i diskutira, kako klijent ne bi krivo interpretirao poruku filma i uopće svrhu gledanja zbog koje mu ga je terapeut »propisao«. Postoji nekoliko praksi gledanja filma: terapeut može savjetovati klijentu da pogleda cijeli film sam kod kuće ili je pak moguće odgledati ulomak filma za vrijeme terapije te ga odmah prodiskutirati. Ako se pak radi o grupnoj terapiji, film se može pogledati za vrijeme zajedničkog susreta.

Likovi nekog filma mogu djelovati poput ko-terapeuta nudeći nadu i ohrabrenje te preoblikovanje vrijednosnog sustava. ${ }^{44}$ Vjerujemo da su filmske metafore sposobne utjecati na oblikovanje alternativnih ponašanja koja vode do sretnijeg i smislenijeg života, kao i ohrabriti klijenta da zauzme nove stavove, što može pozitivno utjecati na psihičko zdravlje. Neka filmska priča možda će alkoholičara »natjerati« da si napokon prizna da je alkoholičar ili pak potaknuti osobu da shvati kako se cilj može postići upornošću i trudom. U tom smislu Sunderland tvrdi da je filmska metafora »terapijsko oruđe koje djeluje poput katalizatora za poticajnu promjenu $\ll^{45}$

\footnotetext{
${ }^{40}$ Usp. Mimi CHRISTIE, Mary MCGRATH, Taking up the challenge of grief. Film as therapeutic metaphor and action ritual, Family Therapy, 8 (1987) 4, 193-199, 195.

${ }^{41}$ Usp. Heston, Kottman, Movies as Metaphors...

${ }^{42}$ Usp. Weeding, Movies and Psychotherapy...

${ }^{43}$ Usp. Berg-Cross, Jennings, Baruch, Cinematherapy...

${ }^{44}$ Usp. Georgios K. LAMPROPOULOS, Nikolaos KAZANTZIS, Frank P. DEANE, Use of Motion Pictures in Clinical Practice, Psychologists' use of motion picture in clinical practice, Professional Psychology. Research and Practice, 35 (2004) 5, 535-541.

${ }^{45}$ Christian C. SUNDERLAND, Brief group therapy and the use of metaphor, Groupwork, 10 (1997) 2, 126-141, 139.
} 


\subsection{Kako i kada koristiti filmove u logoterapiji?}

Problemi uz koje se mogu primjenjivati filmovi u logoterapijskoj praksi su brojni: od napuštenosti, posvajanja, seksualnog iskorištavanja i seksualnih disfunkcija, ovisnosti, straha od smrti i umiranja, do rastave braka, problematičnih partnerskih i obiteljskih odnosa, poremećaja u prehrani i slično. Filmoterapija se može koristiti u individualnoj i grupnoj terapiji, a posebno je pogodna za klijente do kojih je teško emotivno doprijeti. Hesley i Hesley preporučuju da se film ne koristi s malom djecom, klijentima s ozbiljnim psihozama, parovima kod kojih postoji nasilje u obitelji niti kod klijenata koji su nedavno proživjeli traumu. ${ }^{46}$ Ukoliko je klijent doživio neku tešku traumu (PTSP kao posljedicu rata, seksualnog iskorištavanja i sl.) mogao bi se uznemiriti i pojačati simptome nakon gledanja filma koji govori o temi koja je vezana uz uzrok njegove traume (npr. Spašavanje vojnika Ryana ako se radi o ratnim traumama), pa se stoga ne preporuča koristiti tu vrstu filmova jer bi njihovo gledanje moglo nanijeti više štete nego koristi. ${ }^{47}$

Važno je naglasiti da korištenje filma u terapijske svrhe zahtijeva pažnju i promišljanje baš kao i svaka druga terapijska intervencija. Filmoterapija nije samo gledanje filma, već je važno slijediti proces od pripreme klijenta za film do završne diskusije o filmu s terapeutom. Prema Lindi Berg-Cross i suradnicima, postoje četiri koraka o kojima valja voditi računa kada se koristi tehnika filmoterapije. ${ }^{48}$ Prva je da klijent aktivno i savjesno radi na nekom problemu i da mu poveznica između terapijskog problema i predloženog filma mora biti jasna. Ukoliko poveznica između sadržaja filma i klijentova života nije dovoljno jasna, klijent može pribjeći nijekanju, racionalizaciji ili ignoriranju onoga što terapeut želi postići. Drugi korak uključuje terapeutovo htijenje da produbi razinu ili proširi pitanja na kojima klijent radi nastojeći ga potaknuti da istražuje i iskusi nove interpretacije i rješenja. Treći korak je u tome da terapeut adekvatno pripremi klijenta za gledanje filma, što zahtijeva razgovor s klijentom zašto je određeni film predložen, te gdje, kada i s kime ga gledati. U četvrtom se koraku razvija diskusija o filmu i to ubrzo nakon što je film pogledan, što će najčešće biti na susretu koji slijedi. Moguća pitanja koja terapeut može postaviti klijentu nakon odgledanog filma jesu: »Na koji je način lik u filmu riješio svoj problem?«, »Jeste li se mogli poistovjetiti s nekim od likova?«, »Što biste Vi učinili na njegovom/njezinom mjestu? itd.

Nisu međutim svi klijenti pogodni za terapiju filmom. Greške koje se mogu potkrasti terapeutu jesu da, na primjer, ne vodi računa o učincima koje bi film mogao ostaviti na klijenta, mogućnost da klijent ima jaču reakciju od očekiva-

\footnotetext{
${ }^{46}$ Usp. John HESLEY, Jan HESLEY, Rent two films and let's talk in the morning. Using popular movies in psychotherapy, New York, John Wiley \& Sons Inc., 2001.

${ }^{47}$ Usp. Stefan E. SCHULENBERG, Psychotherapy and movies. On using films in clinical practice, Journal of Contemporary Psychotherapy, 33 (2003) 1, 35-48, 43.

${ }^{48}$ Usp. Berg-Cross, Jennings, Baruch, Cinematherapy...
} 
ne, da ne vidi poveznicu između svoje situacije i one koja se prikazuje u filmu, te da klijent postane uznemiren zbog činjenice da je terapeut mogao pronaći poveznicu između njega i nekog od antagonista. Iz tog razloga, nije poželjno preporučiti film u kojem postoji lik negativca, za kojega bi klijent mogao misliti da terapeut smatra da sličan njemu, klijentu. Važno je stoga voditi računa o kompatibilnosti klijenta i lika iz filma te biti siguran da se $u$ filmu mogu naći role models kao i realistične mogućnosti koje klijent uistinu može primijeniti u vlastitoj situaciji. ${ }^{49}$ Zbog toga je nužno da terapeut pažljivo izabere film i pripremi klijenta za gledanje. Moguće su također situacije u kojima će klijent sam reći kako se prepoznao u nekom filmu, pa će tada terapeut pogledati film i po mogućnosti ga »ucijepiti« u proces terapije.

Haas sugerira da je u filmoterapiji dobro odabrati žanr humoristične drame u kojoj se dolazi do srži problema upravo kroz humor, no i »ozbiljnije« žanrove, ali koji pribjegavaju humoru i autohumoru. I logoterapija u svojoj terapijskoj praksi naglašava važnost korištenje humora u radu s klijentom, budući da je (auto)humor oblik autotranscendencije ili samonadilaženja koji se nalazi $\mathrm{u}$ području čovjekova duha. Hass tako vjeruje da (auto)humor dopušta klijentu da zadrži zdrav odmak od vlastitog problema, dok je $u$ isto vrijeme sposoban prepoznati i razumjeti što mu valja naučiti i potom činiti. ${ }^{50} \mathrm{U}$ korist tome idu i istraživanja koja su radili Adams i McGuire, a koja su pokazala pozitivne učinke korištenja humorističnih filmova radi smanjenja kliničke depresije i povećanja praga boli. ${ }^{51}$

Važno je naglasiti da terapeutu film treba biti dobro poznat te da ga je po mogućnosti gledao neposredno prije nego što ga je preporučio klijentu. Uz to, terapeut bi trebao pročitati više filmskih kritika, što će mu omogućiti da upozna različite interpretacije filma do kojih bi i sam klijent eventualno mogao doći pri gledanju filma, a koje su možda različite od početne terapeutove interpretacije i nakane. Također, ponekad će biti potrebno i nekoliko seansi da bi se o filmu raspravilo i shvatilo njegovo značenje, kako za klijenta tako i za terapiju u cjelini.

Tyson dijeli gledanje filma na četiri osnovne faze. Prvu fazu naziva disocijacijom, a to je razdoblje dok se klijent uživljava u radnju i likove te prestaje biti svjestan vlastite realnosti, iako još ne povezuje sebe i priču. U drugoj fazi, koju on naziva fazom identifikacije, klijent povezuje i svjestan je sličnosti filmske priče i likova s vlastitim životom. Treća faza naziva se internalizacija u kojoj klijent pounutrašnjuje sadržaj filmske priče, tj. ono što je vidio i čuo sada usvaja u svoj unutrašnji referencijalni okvir. Posljednja faza naziva se transfer ili pri-

\footnotetext{
${ }^{49}$ Usp. John HESLEY, Reel therapy. Movie are the hot new prescription, Psychology Today, 33 (2000) 1, 54-57.

${ }^{50}$ Usp. Usp. William J. HAAS, The application of cinema in the practice of psychotherapy, Michigan, Ann Arbor UMI Dissertation Services, 1996.

${ }^{51}$ Usp. Elizabeth R. ADAMS, Francis A. McGUIRE, Is laughter the best medicine? A study of the effects of humor on perceived pain and affect. Activities, Adaptation, and Aging, 8 (1986), $157-175$.
} 
jenos onoga iz filma na ono što klijent osjeća i misli, pa je tu riječ o promjeni osjećaja, stava i ponašanja. ${ }^{52}$

\subsubsection{Filmska tehnika autobiografije}

Tehnika filmoterapije koja je osmišljena posebno unutar logoterapijskog pravca temelji se na Eisenbergovom pitanju koje terapeut može postaviti klijentu nakon odgledanog filma: »Da snimaju film o Vašem životu, kako bi se film zvao? ${ }^{53} \mathrm{Tu}$ su ideju dvojica logoterapeuta, Robert Hutzell i Paul Welter, razvili u dvije filmske vježbe i to u slučajevima kada se osobe muče s pitanjem smisla i/ ili identiteta, a kroz koju razvijaju mogućnost učenja iz prošlih iskustava te postavljanja budućih životnih ciljeva. Prvu vježbu čini pronalaženje životne svrhe do tadašnjeg trenutka terapije. Klijentu se daje mogućnost da izmašta film o vlastitom životu. On sam bira budžet za film (mali, srednji, veliki), ovisno već o tome koliko je imao novaca do tog trenutka ili na temelju toga koliko vrednuje novac u vlastitom životu. Zatim bira žanr filma koji se temelji na osobnom životnom iskustvu (vestern, komedija, romansa, horor, akcija, pustolovni itd.). Glavnog glumca (koji će tumačiti klijenta) mogu odabrati i klijentova obitelj i prijatelji na temelju onoga što oni misle tko bi ga najprikladnije tumačio. Nakon toga klijent mora zamisliti filmsku ekipu kako odlazi na set i snima film o njegovu dotadašnjem životu, a onda se vraća s vrpcom koja je spremna za montažu i distribuciju u kinodvorane. Na taj način osobe »pišu « određenu vrstu autobiografije te pokušavaju pronaći smisao u prošlim događajima koji su ih zadesili, suočiti se s lijepim i teškim trenucima i osvijestiti si da su, usprkos svega, još uvijek živi te da sigurno u njihovom životu ima puno toga lijepoga na čemu mogu biti zahvalni, ali možda i propusta s kojima se treba suočiti i oprostiti si ili tražiti oproštenje.

Druga vježba se radi približno šest mjeseci kasnije. Riječ je o nastavku prvog filma koji je postigao velik uspjeh u kinima. Taj se nastavak mora temeljiti na radnji od tadašnjeg trenutka klijentova života prema budućnosti. Klijent piše scenarij i režira film na temelju događaja i odnosa koji će, prema njegovoj procjeni, biti važni u njegovoj budućnosti. Koje bi ciljeve klijent želio postići? Koje prepreke mora nadići? S kime će podijeliti svoj život u budućnosti? Kao i u prvom filmu, i sada klijent mora odrediti budžet za snimanje, likove, glumce, naslov, žanr i dr. Kroz ovu vježbu osoba si osvješćuje vlastite snove i želje koje bi mogla i željela ostvariti u budućnosti kako bi živjela smislenije i izašla iz možebitnog egzistencijalnog vakuuma, te shvatila da je odgovorna za svoj život i izbore koje čini.

\footnotetext{
${ }^{52}$ Usp. Lawrence E. TYSON i dr., The process of cinematherapy as a therapeutic intervention, Alabama Counseling Journal, 26 (2000) 1, 35-41.

${ }^{53}$ Usp. Miriam EISENBERG, Rehumanizing university teaching, The International Forum for Logotherapy, 8 (1985), 44-46.
} 
Kao konkretan primjer navodimo Welterovo svjedočanstvo o korištenju ove logoterapijske filmske tehnike u grupi s muškim adolescentima kojima je bila dijagnosticirana lagana mentalna retardacija i poremećaji u seksualnom ponašanju. Mnogi od tih mladića bili su fizički ili seksualno zlostavljani u djetinjstvu. Welter je primijetio da je vježba s filmom bila učinkovita te im je olakšala diskusiju o temama poput formiranja identiteta, stigmi koje su zadobili zbog neprikladnog ponašanja, interpersonalnih odnosa te izbjegavanja budućih seksualnih agresivnih ponašanja. Filmska vježba omogućila je tim mladim osobama alternativne načine pričanja vlastite životne priče, prepoznavanje vlastite vrijednosti i pronalazak smisla u prošlim događajima, kao i postavljanje prioriteta za budućnost. ${ }^{54}$

\subsubsection{Pozitivni učinci filmoterapijske tehnike}

Mnogo je pozitivnih primjera koje donose klinički psiholozi kada je riječ o filmoterapiji. Heston i Kottman tako navode slučaj 39-godišnje klijentice Viktorije. Naime, ona je patila od depresivnih faza, posljednja u trajanju od šest mjeseci, koje je pripisivala neriješenim emotivnim konfliktima proizašlim iz nezadovoljavajućeg odnosa s majkom. Konstantno je krivila majku za sve svoje probleme. Terapeut joj je dao zadatak da pogleda film Lost in Yonkers, u nada da će joj pomoći u poboljšanju odnosa s majkom. Film je kroz svoje prikazivanje odnosa majke i djece pacijentici pomogao da sagleda situaciju iz perspektive vlastite majke, da se stavi u njenu »kožu« i tako postane empatičnija i objektivnija prema njoj. Ta joj je filmska priča omogućila da shvati kako majčino ponašanje proizlazi iz njene vlastite patnje te je ubrzo prestala nesporazume shvaćati na osobnoj razini, što je doprinijelo uspostavljanju zdravog i zrelog odnosa s majkom. ${ }^{55}$ Suarez pak navodi 53 -godišnju klijenticu Ingrid koja je imala problema u partnerskim odnosima. Naime, ona se borila s poslovnim brigama, romantičnim vezama i obiteljskim problemima koji su, prema terapeutkinji, proizlazili iz njenog osjećaja manje vrijednosti. U ovom slučaju, klijentica je sama donijela na seansu film, jer se usporedila s protagonisticom iz filma, što je bilo katalizator koji je transformirao njezin život. ${ }^{56}$

Spomenimo i primjer iz Schulenbergove filmoterapijske prakse u kojem spominje jednog klijenta koji je patio od opsesivno-kompulzivnog poremećaja, a kod kojeg je primijenjen kognitivno-bihevioralno-logoterapijski pristup zajedno s uzimanjem medikamenata. Međutim, klijent se borio s problemom osjećaja besmisla i beznađa koja su ga obuzimala u "praznome hodu « između dvije seanse, pa mu je terapeut predložio da pogleda film Brodolom života

\footnotetext{
${ }^{54}$ Usp. Paul R. WELTER, Logotherapy-Intermediate. Franklian psychology and logotherpy, The Viktor Frankl Institute of Logotherapy, Abilene, 1995.

${ }^{55}$ Usp. Heston, Kottman, Movies as Metaphors...

${ }^{56}$ Usp. Elizabeth SUAREZ, A princess in God's eyes. Cinematherapy as an adjunctive tool, Journal of Psychology and Christianity, 22 (2003) 259-261.
} 
Roberta Zemeckisa. Film se ne tiče kompulzivno-opsesivnog poremećaja, već govori o čovjeku koji je doživio avionsku nesreću te četiri godine živio sam na pustom otoku, nalazeći se u, izvana gledano, beznadnoj situaciji. No on nije izgubio nadu usprkos vanjskim negativnim uvjetima. Riječ je tu o univerzalnoj temi koja na metaforički način govori o »nasukanosti« u pustinji života, kada nam vanjske okolnosti ne pogoduju, kada smo suočeni sa sudbinskim situacijama koje nismo sami odabrali i koje nam se ne sviđaju, ali koje ljudski duh jest $u$ stanju nadići i tako se spasiti (slično kako o tome govori i sam Frank ${ }^{57}$ kada opisuje iskustva u koncentracijskom logoru). Gledanje filma klijentu je pomoglo u prevladavanju osjećaja beznađa u vremenu kad nije na seansi gdje se dotada jedino osjećao dobro i sigurno. ${ }^{58} \mathrm{U}$ tom smislu navedimo i empirijsko istraživanje Michaela Powella o vjerodostojnosti filmoterapije, u kojem je mjerio njen učinak na stupanj beznađa kod jednog klijenta koji je patio od teške depresije. U njegovu se slučaju radilo o 11-tjednom praćenju klijenta prije, za vrijeme i nakon grupnog gledanja filma Gospodar prstenova: Prstenova družina, a rezultati pokazuju da se stupanj depresije kao i osjećaj beznađa i nedostatak optimizma znatno smanjio kroz terapiju filmom, baš kao i kod Schulenbergova klijenta. ${ }^{59}$

\subsection{Koje filmove koristiti u logoterapiji?}

Neki autori, poput Bertolina, savjetuju da svaki terapeut napravi vlastitu listu filmova koje bi mogao preporučiti klijentima, ${ }^{60}$ te koje je on sam pogledao više puta i drži da su adekvatni za određeni tip problema. »Terapijske« filmove nije preporučljivo birati prema dijagnozama nego prema životnim situacijama koje su stvarni uzrok određenih psihičkih stanja.

Za koje bismo filmove mogli reći da su dobri? Nažalost, za to ne postoje neka univerzalna mjerila niti neki općevažeći popisi. Filmovi koji bi se mogli primijeniti u logoterapijskoj praksi su oni koji u središtu priče imaju likove koji su, usprkos životnim ograničenjima, bolestima i razočaranjima, iz života uspjeli izvući najbolje, prevladati krize i osmisliti vlastiti život a da se ne predaju očaju i malodušju. Zatim filmovi koji govore o herojskim činima u kojima su pojedinci bili spremni žrtvovati sebe za više ideale i ciljeve, autotranscendirajući, ostajući čovjekom u punom smislu riječi i u teškim trenucima poput rata ili prirodnih katastrofa, prakticirajući nesebičnost i plemenitost. Također se slažemo s autorima koji tvrde da je učinkovito ako lik u filmu nadilazi životne

\footnotetext{
${ }^{57}$ Usp. Frankl, Život uvijek ima smisla...

${ }^{58}$ Usp. Schulenberg, Psychotherapy and movies..., 39.

${ }^{59}$ Usp. Michael L. POWELL, Improving the Empirical Credibility of Cinematherapy. A SingleSubject Interrupted Time-Series Design, Counseling Outcome Research and Evaluation, 1 (2010), 40-49.

${ }^{60}$ Usp. Bob BERTOLINO, Lights, camera, action!!! Making new meaning through movies, u: Howard G. ROSENTHAL (ur.), Favorite Counseling and Therapy Homework Assignments, Philadelphia, Sheridan Books, 2001, 69-73.
} 
prepreke autohumorom, vjerom i prkosom vlastita duha, kao što nam to, na primjer, pokazuje protagonist filma Život je lijep Roberta Benignija, poručujući da društvo možda nije zdravo, ali je ozdravljivo. Filmovi pak koje bi trebalo izbjegavati jesu oni koji gledaju na čovjeka u determinističkim okvirima, tj. kao onoga čiji je život određen izvanjskim silama i okolnostima. Isto tako, filmovi koji zastupaju beznadnu sliku svijeta mogu destruktivno djelovati na čovjekov duh. A ono što je Elizabeth Lukas rekla za dobru knjigu, mi prenosimo sada na film: on će terapijski pomoći

»ako njezin pisac (redatelj, op.a.) vjeruje u to da ima putova da se 'održimo iznad kaosa' i ako on svoje čitatelje (tj. gledatelje, op.a.) dovoljno ljubi da bi radi njih za takvim putovima tragao. Nadalje, neka je knjiga (film, op.a.) dobra onda kada je kadra biti 'prijatelj duše': iskrena, poticajna, zabavna, utješna, nadahnjujuća kakvi prijatelji upravo i jesu. « ${ }^{61}$

U okviru ovog rada mogli bismo izdvojiti nekoliko filmova za koje držimo da su »ljekovite priče« te koji implicitno sadrže logoterapijski pristup problemu. Jedan od njih je kratkometražni igrani film Cirkus leptira Joshue Weigela. Radnja ovog dvadesetominutnog filma odvija se u neobičnom cirkusu u kojemu karizmatični vlasnik Mendes okuplja ljude koji su naučili svoje nedostatke pretvarati u prednosti, te time postali atrakcija i izazov za posjetitelje cirkusa. Cijela se priča događa u vrijeme Velike depresije u SAD-u. Glavni lik Will, koji je rođen bez ruku i nogu (tumači ga Nick Vujičić), paraliziran je osjećajem samosažaljenja zbog svojeg fizičkog hendikepa te naposljetku završava u Cirkusu leptira. Zahvaljujući potpori ljudi iz tog cirkusa, Will prolazi kroz emotivnu i duhovnu katarzu, postajući nadahnuće drugima i nalazeći smisao svog postojanja koji mu je do tada bio sakriven. Ako film želimo čitati u logoterapijskom ključu, potrebno se zaustaviti na jednoj od središnjih rečenica i misli filma koju Mendes (koji metaforički predstavlja Boga) upućuje Willu:

»Ali ti? Proklet od rođenja! Čovjek - ako ga tako možete zvati - kojemu je i sam Bog okrenuo leđa. Ako ti vjeruješ u ovo, tako će te vidjeti i drugi ljudi oko tebe. Zato, pogledaj ljepotu koja dolazi iz sjećanja i znaj da nisi sam!«

Pod kakvim ćemo uvjetima doći na ovaj svijet ne biramo sami; hoćemo li biti fizički zdravi i pokretni ili ne nije stvar naše slobodne volje niti našeg izbora, ali kako ćemo se s time nositi i što ćemo s time učiniti ovisi samo o nama i vjeri da život i sve što nam on donosi ima smisla, baš kao i patnja, te da su naši potencijali mnogo veći nego što se to na prvi pogled čini. Tada je i u najbezizlaznijim situacijama moguće pronaći smisao. To je poruka smisla koju nudi ovaj kratkometražni igrani film i koji može biti poticaj svima koji se nalaze u besmislu i/ili depresiji zbog udaraca sudbine na koje nisu mogli utjecati.

Filmove koje smatramo da treba ponuditi u psiho/logoterapijskoj praksi stoga što njihovi protagonisti pronalaze smisao i u najtežim životnim okol-

${ }^{{ }_{11}}$ Lukas, Što nas u životu pokreće...., 123. 
nostima, kada se čini da izlaza nema oni ne odustaju od borbe i slijeđenja vlastitih snova, iskazuju prkos duha, autohumor i samonadilaženje u kriznim situacijama, uče iz vlastitih pogrešaka i spremni su se mijenjati nabolje ili su spremni svoj život žrtvovati za više ideale vraćajući nam vjeru u ljudsku dobrotu, jesu sljedeći: Adamove jabuke (Anders Thomas Jensen, 2005.), Babettina gozba (Gabriel Axel, 1987.), Bagdad Café (Percy Adlon, 1987.), Brodolom života (Robert Zemeckis, 2000.), Cirkus leptira (Joshua Weigel, 2009.), Čokolada (Lasse Hallstrom, 2000.), Dva dana, jedna noć (Jean-Pierre i Luc Dardenne, 2014.), Gravitacija (Alfonso Cuaron, 2013.), Invictus (Clint Eastwood, 2009.), Joy (David Russell, 2015.), Kralj lavova (Roger Allers, 1994.), Mala miss Amerike (Jonathan Dayton, Valerie Faris, 2006.), Marsovac (Ridley Scott, 2015.), Nakon vjenčanja (Susanne Bier, 2006), Nedodirljivi (Olivier Nakache i Éric Toledano, 2011.), Otporan na vatru (Alex Kendrick, 2008.), Patch Adams (Tom Shadyac, 1998.), Pijev život (Ang Lee, 2012.), Put (Emilio Estevez, 2010.), Schindlerova lista (Steven Spielberg, 2003.), Tri boje: Plavo (Krszystof Kieslowski, 1993.), U dobru i u zlu (David O. Russell, 2012.), Život je lijep (Roberto Benigni, 1997.), Životi drugih (Florian Henckel von Donnersmarck, 2006.).

Popis filmova koji bi se mogli koristiti u logoterapijskoj praksi daleko je veći od ovdje donesenog izbora. Ove su filmove autori članka i sami pogledali te vjeruju da oni sadrže ljekovite metafore. Jedan od kriterija pri izradi popisa bila je i popularnost filmova te njihova dostupnost na hrvatskom tržištu. Stoga naslovi koji se ovdje spominju mogu pružiti tek orijentaciju i polazišnu točku za one koji se žele baviti filmoterapijom u okviru logoterapije. Naravno, svatko bi trebao sastaviti svoj osobni popis filmova za koje drži da mogu biti korisni u okviru logoterapijske prakse jer u nekom segmentu odražavaju Franklovo učenje o liječenju smislom.

\section{Zaključak}

Različite su mogućnosti korištenja filma u logoterapijske (psihoterapijske) svrhe o kojima smo u našem radu govorili. Jedan od temeljnih psihoterapijskih zadataka jest pomoći klijentu da dođe do ciljeva koje si je postavio, ukoliko su ti ciljevi realni, konkretni, specifični, dogovoreni s terapeutom. Dolazak do ciljeva ostvaruje se na različite načine kao i u različitim vremenskim razmacima. Kada i kako će klijent doći do cilja ovisi o mnogo faktora, a jedan od tih faktora može biti ispravno i pravodobno korištenje raznih tehnika u procesu psihoterapije. Tehnika koju smo u ovom radu htjeli naglasiti jest korištenje filma, s posebnim naglaskom na logoterapijski smjer u psihoterapiji. Vidjeli smo da je filmoterapiji preteča biblioterapija. Budući da je film danas rašireniji od knjige, kao i mogućnosti gledanja filma prema vlastitom izboru, s razlogom možemo govoriti o opravdanom korištenju filma i u logoterapiji. Budući da je logotera- 
pija psihoterapijski smjer koji naglašava pronalaženje smisla u ljudskom životu, vidimo veliku i konkretnu mogućnost primjene filma u njoj, jer upravo se u filmu često obrađuju egzistencijalne teme. Kada i koji film koristiti ovisi o terapeutovu osluškivanju potrebe klijenta kao i njegovim osobnim prioritetima. Sloboda i odgovornost, patnja, humor, tjeskoba, izbor i odluka, teme su koje se obrađuju u logoterapiji, a o kojima i klijent, koji traži pomoć, može slušati i gledati kroz filmska ostvarenja. Naravno, kao i u mnogim drugim psihoterapijskim smjerovima, riječ je o psihoterapeutovu umijeću da poveže sadržaj filma s osobnom poviješću klijenta, i obrnuto.

Želimo naglasiti važnost korištenja filma u logoterapijske, ali i općenito u psihoterapijske svrhe, te potaći daljnja promišljanja i istraživanja o ovoj temi. U današnjem vremenu, kada kod mnogih ljudi primjećujemo borbu s egzistencijalnim poteškoćama, potaknuti nekog čovjeka na pronalaženje smisla može mu olakšati hod prema zadanom ili pak otkrivenom smjeru, putu, cilju. 


\section{Irena Sever Globan* - Josip Bošnjaković*** \\ Film as a healing metaphor in logotherapeutic practice \\ Summary}

Man uses different techniques and tools in order to help himself or others and enhance the quality of life. This paper assumes that stories and visual metaphors are soul-healing if honest, encouraging, consoling and inspiring, thus aiding man in overcoming different psychological and existential problems. Special emphasis is placed on the healing powers of film stories and cinematherapy which is increasingly used as a supporting technique in various psychotherapies and is a successor of bibliotherapy which is still frequently used in logotherapy. That line of psychotherapy founded by Viktor Frankl attempts to provide an answer to the question of existential emptiness that ails the modern man more often and it occurs due to the impossibility of discovering meaning. This paper tries to answer the question how film stories, often evolving around existential matters (who am I, where do I come from and where am I going) can aid the persons struggling with making sense out of their own life and problems of suffering, freedom and responsibility as well as which films to suggest to clients in logotherapy practice (as well as other psychotherapies).

Key words: film, psychotherapy, logotherapy, healing stories, visual metaphors.

(na engl. prev. Marko Globan)

\footnotetext{
* Irena Sever Globan, PhD, Assistant Professor, Department of Communication Studies, Catholic University of Croatia; Address: Ilica 242, HR-10000 Zagreb, Croatia; E-mail: irena.sever@ unicath.hr.

**Josip Bošnjaković, PhD, Department of Psychology, Catholic University of Croatia; Address: Ilica 242, HR-10000 Zagreb, Croatia; Faculty of Catholic Theology in Đakovo, Josip Juraj Strossmayer University of Osijek; Address: Petra Preradovića 17, HR-31400 Đakovo, Croatia; E-mail: jobosnjakovic@gmail.com.
} 